\title{
Zeytin Fidan Gelișimine Mikrohavza Su Hasadı Tekniği İle Toprak Su Tutma Kapasitesini Artırıcı Bazı Uygulamaların Etkisi
}

\author{
Süleyman ȘEN ${ }^{1 * *}$ GD Gülay YILMAZ'ID Tuncay TOPDEMIR' ID Ümit ALKAN' ID
}

'Uluslararası Tarımsal Araștırma ve Eğitim Merkezi, Menemen / İzmir / Türkiye

\begin{abstract}
*Sorumlu yazar e-mail (Corresponding author e-mail): suleyman.sen@tarimorman.gov.tr
Geliș tarihi (Received): 09.07.2019

Kabul tarihi (Accepted): 19.07.2019

DOI: 10.21657/topraksu.655561
\end{abstract}

Öz

Bu çalıșma, yarı dairesel mikrohavza su hasadı tekniği ile toprağın su tutma kapasitesini iyileștirici bazı uygulamaların zeytin fidan gelișimine etkisini incelemek amacıyla yapılmıștır. Deneme tesadüf blokları deneme deseninde kurulmuș olup fidanların dikimi 2014 yılı Kasım ayında, yarı dairesel (kaș) tipi mikrohavza su hasadı seddeleri ise 2015 yılı Mayıs ayında yapılmıștır. Deneme konuları; A Kontrol konusu: Dar çukura yöresel dikim, B konusu: Tașlardan ayıklanmıș toprağa dikim (1x1x1 m'lik fidan çukuruna), C konusu: B konusu toprağına $50 \mathrm{~kg}$ O.G. (organik materyal) eklenmiș fidan çukuruna dikim. D konusu: C konusu toprağına $250 \mathrm{gr}$ polimer (su tutucu) ilave edilmesi, E konusu: C konusu toprağına 500 gr polimer ilave edilmesi ile olușturulmuștur. Konu toprakların nem içerikleri $25 \mathrm{~cm}$ ve $75 \mathrm{~cm}$ derinliğe yerleștirilen nem sensörleriyle saatlik olarak toprak nemleri ölçülmüș ayrıca yağıș, hava sıcaklığı, nispi nem ve rüzgâr hızı deneme alanına kurulan meteoroloji istasyonu ile ölçülmekte ve internet ortamında izlenmektedir.

Denemenin 1. yılı sonu 2015 yılı Ekim ayında ölçülen fidan gövde çapları kesit alanı istatistik analize tabi tutulmuș ve konular arası fark \%95 güvenle önemli bulunmuștur. Buna göre konuların ortalama fidan gövde çap kesit alanları sırasılyla, D: $133.09 \mathrm{~mm}^{2}$, E: $105.48 \mathrm{~mm}^{2}$, C: $98.98 \mathrm{~mm}^{2}$, B: $94.27 \mathrm{~mm}^{2}$ ve A konusu $77.95 \mathrm{~mm}^{2}$ olmuștur. 2016 yılı sonunda da fidanların gövde kesit alanları arasındaki fark istatistiki olarak \%95 güvenle önemli olurken, D konusu 459.98 mm2 ile yine ilk sırada yer almıș bunu sırasıyla B: 445.14. mm2, E: $432.94 \mathrm{~mm} 2$, C: $404.35 \mathrm{~mm} 2$ ve A konusu $206.67 \mathrm{~mm}^{2}$ takip etmiștir. Projenin iki yllı sonunda zeytin fidanların gövde kesit alanı artıșı istatistiksel olarak önemli çımıș olup D konusu ilk sırada yer almıștır. Yörede yeni dikilen zeytin fidanların sulama olmadan yetișmediği dikkate alındığında mikrohavza su hasadı tekniğinin ve toprağın su tutma kapasitesini iyileștirici etmenlerin fidan gelișimine olumlu etkileri olmuștur.

Anahtar kelimeler : Mikrohavza su hasadı, organik materyal, polimer, toprak nemi, zeytin

\section{Effect of Micro Catchment Water Harvesting Technique and Some Applications that Improve the Soil Water Holding Capacity on Growth of Olive Sapling}

\section{Abstract}

The aim of this study is to examine the effects of semi-circular water harvesting techniques and some applications that improve soil water holding capacity to growing of olive trees. Experiment has been established in randomized block design, and micro catchment water harvesting bunds which are semicircular type were constructed in May 2015. Experiment subjects; A: the control subjects, local planting, 
B: planting in soil cleared it of stones (in $1 \times 1 \times 1 \mathrm{~m}$ sapling pit), C: adding $50 \mathrm{~kg}$ of soil organic material $(\mathrm{OM})$ to soil cleared it of stones, D: adding $250 \mathrm{~g}$ polymer (water retainer) to soil containing $50 \mathrm{~kg}$ soil organic material and cleared it of stones, E: adding $500 \mathrm{~g}$ polymer to soil containing $50 \mathrm{~kg}$ soil organic material and cleared it of stones. The moisture content of experimental soils has been measured on an hourly basis with moisture sensors placed $25 \mathrm{~cm}$ and $75 \mathrm{~cm}$ in depth, as well as precipitation, air temperature, relative humidity and wind speed has been recorded by meteorological station and monitored by an internet application. Trunk diameter of sapling was measured in October 2015 is that at the end of first year of the experiment, and according to experimental subjects, annual differences in sapling trunk diameter cross sectional area was subjected to statistical analysis. The differences between saplings was a 95\% probability. Accordingly, the most increase was in D subject with $133.09 \mathrm{~mm}^{2}$, it was followed by E: $105.48 \mathrm{~mm}^{2}$; C: $98.98 \mathrm{~mm}^{2}$; B: $94.27 \mathrm{~mm}^{2}$ and $\mathrm{A}: 77.95 \mathrm{~mm}^{2}$ respectively. While the change in saplings trunk cross-sectional area at the end of second year of the experiment was statistically reliable at $95 \%$ probability, D subject was ranked at first group with $459.98 \mathrm{~mm}^{2}$. It was followed by B subject with 445.14. $\mathrm{mm}^{2}$, E: $432.94 \mathrm{~mm}^{2}$, C: $404.35 \mathrm{~mm}^{2}$ and A subject with $206.67 \mathrm{~mm}^{2}$ respectively.

Keywords: Micro-catchment water harvesting, soilmoisture, organicmaterial, polymer, olive

\section{Gíriș}

Küresel ısınmayla birlikte iklimin değișmesi ve artan nüfus, su kaynakları üzerine olan talebi ve baskıyı gün geçtikçe artırmaktadır. Bu nedenle Türkiye'de su kaynaklarının etkili kullanımı son derece önemlidir. Türkiye'de yıllık yağıș ortalaması 643 mm olup, bu miktar yaklașık 501 milyar $\mathrm{m}^{3}$ suya karșılık gelmektedir. Bu suyun büyük bir kısmı buharlașma, evapotransprasyon ve nehir akımları ile uzaklașırken komșu ülkelerden de yılda ortalama 7 milyar $\mathrm{m}^{3}$ su gelmektedir. Bu durumda toplam yerüstü suyu potansiyeli 193 milyar m³ olmaktadır (DSi, 2013).

Ülkemizde yağıș dağılımı 250 - 2500 mm arasında değișmekte olup yağıș rejimi bölgelere göre düzensizlikler göstermektedir. Ülkemizin pekçok alanında yağıșa dayalı tarım yapılmakta ve yağıș rejimindeki değișiklikler bazen ürün verimini olumsuz yönde etkilemektedir. Bu nedenle yağıșa dayalı tarım yapılan yerlerde yağıș düzensizliklerini bertaraf etmek için su hasadı oldukça önemlidir. Yağıșın büyük bir su toplama alanından, küçük bir hedef alanda kullanılmak üzere yüzey akıș olarak toplanması süreci olarak tanımlanan su hasadı (Oweis vd., 1999), suyun farklı kaynaklardan farklı amaçlarla kullanımı için toplanması ve korunması metotları (Boers ve Ben-Asher., 1980) olarak da ifade edilebilmektedir. Su hasadı uygulamaları, kurak ve yarı kurak bölgelerde yağmur suyu yönetiminin geliștirilmesinde önemli bir yol olup bitki örtüsünü geliștirmek ve erozyonu azaltmak için de etkili bir yöntemdir.

Günümüzde iklim değișikliğinin etkisiyle, șiddeti ve miktarı değișen yağıșlardan yararlanmak son derece önemli bir konu haline gelmiștir. Temel ilkesi arazinin bir bölümüne düșen genellikle küçük ve verimsiz yağmur suyu payını bir bașka bölümün payına eklemek (Oweis vd., 2001) olan su hasadı, kurak alanlarda geçmișten günümüze su sağlamada oldukça yaygın șekilde kullanılan bir yöntem olmuștur. Su hasadı uygulamaları yeni bir teknoloji değil, geçmișten kalan bir mirastır. Her ne kadar su hasadı teknikleri kurak ya da yarı kurak bölgeler için uygun görünse de yıllık yağıș toplamı yüksek ancak düzensiz olan bölgelerde de su toplama ve toprak muhafaza amaciylada uygulanmaktadır. Su hasadı tekniklerinin temel amacı bitkinin intiyaç duyduğu suyu sağlamak ve bu sayede verimi arttırmaktır. Su hasadı tekniklerinin uygulanması ile tarım sektöründe yüzey akıș suyu dağıım etkinliği arttırıır ve toprak kalitesinin sürdürülebilirliği sağlanır (AlSeekh ve Mohammad, 2009). Ek olarak bazı su hasadı yöntemleri ile daha önce hiçbir ürün yetiștirilmeyen alanlarda tarımsal üretimi mümkün hale getirmektedir (Anschütz vd., 2003)

Bu çalıșmanın amacı, yarı dairesel (kaș tipi) mikro havza su hasadı tekniğinin ve toprak su tutma kapasitesini iyileștirici bazı uygulamaların toprak nem hacmi ile yeni dikilmiș zeytin fidanlarında büyüme parametrelerine olan etkilerini araștırmaktır. Bu amaçla olușturulan deneme konularının toprak nem hacmi, toprak karakteristikleri ile bitki gelișim parametreleri üzerindeki etkileri, yapılacak olan teknik ve fenolojik gözlemler ile belirlenecek olup ilk iki yılla ait elde edilen veriler değerlendirilmiștir. 


\section{MATERYAL VE YÖNTEM}

Çalıșma, Türkiye'nin güneyinde yer alan Köyceğiz ilçesinin 5 km kuzeyinde, Yeșilköy sınırları içerisinde yer alan Uluslararası Tarımsal Araștırma ve Eğitim Merkezi'ne ait Deneme ve Demonstrasyon İstasyonu (D.D.i.)'nda yürütülmektedir. Köyceğiz ilçesinin uzun yıllara ait bazı iklim verileri Çizelge 1'de verilmiștir. Köyceğizin uzun yıllar ortalama sıcaklığı $18.3^{\circ} \mathrm{C}$, ortalama yağıș ise 1083.70 mm'dir.
Deneme alanına, bazı iklim parametrelerini ölçmek amaciyla meteoroloji istasyonu kurulmuș olup, deneme süresince eldilen veriler Çizelge 2'de verilmiștir. Çizelge 2 incelendiğinde 2016 yılında ortalamayağıș 871.6 mm ile uzunyıllar ortalamasının altında kalmıș, ortalama sıcaklık ise $19.9^{\circ} \mathrm{C}$ ile uzun yıllar ortalamanın üzerinde gerçekleșmiștir. Bitkilerin en fazla suya ihtiyaç duyduğu haziran, temmuz,

Çizelge 1. Köyceğiz ilçesi uzun yıllar iklim verileri (1985-2011) (MGM 2011)

Table 1. Köyceğiz climate data for many years (1985-2011)

\begin{tabular}{|c|c|c|c|c|c|c|c|c|c|c|c|c|c|}
\hline AY & 1 & 2 & 3 & 4 & 5 & 6 & 7 & 8 & 9 & 10 & 11 & 12 & Ort. \\
\hline Ort. yağıș (mm) & 182.5 & 160.0 & 112.6 & 60.9 & 35.2 & 12.7 & 6.9 & 5.3 & 28.8 & 88.4 & 163.3 & 227.3 & 1083.7 \\
\hline Ort. sıcaklık ( $\left.{ }^{\circ} \mathrm{C}\right)$ & 9.3 & 9.8 & 12.3 & 16.0 & 21.0 & 26.4 & 29.0 & 28.4 & 24.6 & 19.2 & 13.7 & 10.4 & 18.3 \\
\hline
\end{tabular}

Çizelge 2. Deneme alanına ait bazı meteorolojik veriler (2015-2016)

Table 2. Some meteorological data of the trial area (2015-2016)

\begin{tabular}{|c|c|c|c|c|c|c|c|c|c|c|c|}
\hline \multirow[t]{2}{*}{ Aylar } & \multirow{2}{*}{$\begin{array}{l}\text { Yağıș } \\
\text { [mm] }\end{array}$} & \multicolumn{2}{|c|}{$\begin{array}{c}\text { Rüzgâr hızı } \\
{[\mathrm{km} / \mathrm{s}]}\end{array}$} & \multicolumn{3}{|c|}{ Hava sıcaklığı [ $\left.{ }^{\circ} \mathrm{C}\right]$} & \multicolumn{3}{|c|}{ Nispi nem [\%] } & \multicolumn{2}{|c|}{$\begin{array}{c}\text { Çiğ noktası } \\
{\left[{ }^{\circ} \mathrm{C}\right]}\end{array}$} \\
\hline & & Ort. & Mak & Ort. & Min. & Mak. & Ort. & Min & Mak. & Ort. & Min. \\
\hline \multicolumn{12}{|c|}{2015 su yılı } \\
\hline Temmuz & 0.4 & 3.1 & 16.2 & 29.3 & 19.4 & 40.7 & 48.9 & 12.2 & 90.7 & 16.4 & 4.9 \\
\hline Ağustos & 0.0 & 2.9 & 18.7 & 30.1 & 21.4 & 41.3 & 49.0 & 9.8 & 84.6 & 17.1 & 0.6 \\
\hline Eylül & 69.4 & 2.6 & 21.6 & 26.7 & 17.1 & 42.3 & 58.0 & 12.3 & 96.9 & 16.4 & 7.2 \\
\hline \multicolumn{12}{|c|}{2016 su yilı } \\
\hline Ekim & 343.0 & 0.5 & 5.2 & 21.4 & 10.8 & 31.9 & 63.3 & 22.8 & 99.3 & 13.3 & 2.4 \\
\hline Kasım & 192.8 & 0.7 & 6.3 & 16.9 & 7.4 & 26.9 & 60.1 & 10.2 & 98.6 & 8.1 & -8.7 \\
\hline Aralık & 0.0 & 0.7 & 4.9 & 11.4 & -0.8 & 24.1 & 59.1 & 11.2 & 93.8 & 2.7 & -18.1 \\
\hline Ocak & 86.8 & 1.1 & 8.4 & 9.1 & -3.4 & 22.3 & 67.0 & 12.0 & 100.0 & 2.3 & -19.9 \\
\hline Șubat & 83.8 & 0.9 & 6.1 & 14.0 & 1.6 & 28.4 & 68.3 & 20.1 & 99.4 & 7.5 & -7.0 \\
\hline Mart & 117.8 & 1.1 & 10.9 & 13.8 & 4.1 & 27.0 & 66.0 & 21.1 & 100.0 & 6.6 & -3.0 \\
\hline Nisan & 11.0 & 1.0 & 5.2 & 19.2 & 8.3 & 32.7 & 56.7 & 8.4 & 97.8 & 9.0 & -5.9 \\
\hline Mayıs & 2.0 & 1.1 & 6.0 & 20.5 & 10.4 & 33.2 & 59.7 & 18.3 & 97.6 & 11.3 & 0.5 \\
\hline Haziran & 1.0 & 1.2 & 5.7 & 27.5 & 15.9 & 43.1 & 46.7 & 8.5 & 97.8 & 13.6 & 1.0 \\
\hline Temmuz & 0.0 & 1.1 & 6.1 & 30.2 & 21.2 & 41.1 & 46.1 & 11.6 & 82.8 & 16.1 & 3.9 \\
\hline Ağustos & 0.0 & 1.1 & 4.5 & 29.7 & 21.6 & 39.8 & 51.9 & 12.3 & 84.8 & 17.8 & 3.9 \\
\hline Eylül & 33.4 & 1.1 & 4.9 & 25.5 & 14.2 & 39.4 & 48.9 & 6.9 & 96.4 & 12.7 & -5.7 \\
\hline Top- Ort. Mak. Min & 871.6 & 1.0 & 10.9 & 19.9 & -3.4 & 43.1 & 57.8 & 6.9 & 100.0 & 10.1 & -19.9 \\
\hline
\end{tabular}

Çizelge 3. Memecik zeytin çeșidinin bazı özellikleri

Table 3. Characteristics of olive cultivar

\begin{tabular}{|c|c|}
\hline Orjini & Muğla \\
\hline Çoğrafi Dağılımı & $\begin{array}{l}\text { İzmir, Aydın, Manisa, Denizli, Muğla, Antalya, Sinop, Kahramanmaraș, Kastamonu'ya kadar } \\
\text { uzanan coğrafya. }\end{array}$ \\
\hline Ağaç & Kuvvetli, toplu yuvarlak taç. \\
\hline Yaprak & Orta uzun, geniș eliptik, tüysüz, 53.7×10.84 mm \\
\hline Ciçek & Ort. 29.9 mm somakta ort. 11 çiçek bulunur, 16 Mayıs-6 Haziran dönemi çiçeklenme. \\
\hline Meyve & $\begin{array}{l}\text { Ağırlık } 478 \mathrm{gr} \text {, hacmi } 465.6 \mathrm{~cm}^{2} \text { (100 meyve) } 1 \mathrm{~kg} \text { da } 209 \text { adet, boyu } 25.61 \mathrm{~mm} \text {, eni } 19.4 \\
\text { mm, et oranı \% 88.28, Yağ oranı \% 24.5-28.20 Mayıs-11 Haziran meyve bağlama, } 15 \\
\text { Kasım-15 Aralık siyah olum. }\end{array}$ \\
\hline Cekekirdek & Küçük, oval, simetrik, ağırlık 56 gr, hacmi 52 cm² (100 çekirdek) \\
\hline Değerlendirme & Yağlık ve sofralık \\
\hline İklim & Soğuk ve kuraklığa dayanıklı \\
\hline
\end{tabular}


Çizelge 4. Deneme konularına ait topraklarının bazı fiziksel ve kimyasal özellikleri

Table 4. Some physical and chemical properties of soils

\begin{tabular}{|c|c|c|c|c|c|c|c|}
\hline Konular & $\begin{array}{c}\text { Su ile } \\
\text { doymușluk } \\
(\%)\end{array}$ & $\begin{array}{c}\text { Total Tuz } \\
(\%)\end{array}$ & $\mathrm{pH}$ & $\begin{array}{c}\text { Kireç } \\
\left(\% \mathrm{CaCO}_{3}\right)\end{array}$ & $\begin{array}{c}\text { Yarayıșlı } \\
\text { Fosfor (kg/ } \\
\text { da) }\end{array}$ & $\begin{array}{l}\text { Yarayıșlı } \\
\text { Potasyum } \\
\text { (kg/da) }\end{array}$ & $\begin{array}{c}\text { Organik } \\
\text { Madde (\%) }\end{array}$ \\
\hline A. konu & 57.2 & $E$ & 7.45 & 0.4 & 2.7 & 26.9 & 2.2 \\
\hline B. konu & 50.6 & $E$ & 7.45 & 0.4 & 1.7 & 19.0 & 2.7 \\
\hline C. konu & 48.4 & $E$ & 6.64 & 0.4 & 2.3 & 20.5 & 4.2 \\
\hline D. konu & 72.6 & $E$ & 6.63 & 0.4 & 2.1 & 23.6 & 4.5 \\
\hline E. konu & 66.0 & E & 6.67 & 0 & 2.2 & 23.6 & 4.2 \\
\hline Organik Materyal & 92.4 & $E$ & 7.34 & 0 & 3.7 & 37.6 & 8.5 \\
\hline Konular & Kum (\%) & Kil (\%) & Silt (\%) & Bünye & $\begin{array}{c}\text { Bozulmuș } \\
\text { Tarla Kap. } \\
\text { (\% Pw) }\end{array}$ & $\begin{array}{l}\text { Solma } \\
\text { Noktası (\% } \\
\text { Pw) }\end{array}$ & $\begin{array}{c}\text { Hacim } \\
\text { Ağırlık (g/ } \\
\left.\mathrm{cm}^{3}\right)\end{array}$ \\
\hline A. konu & 58.4 & 15.6 & 26 & $S L$ & 21.37 & 9.13 & 1.47 \\
\hline B. konu & 56.4 & 17.6 & 26 & SL & 21.53 & 9.52 & 1.42 \\
\hline C. konu & 58.4 & 17.6 & 24 & $S L$ & 20.77 & 10.92 & 1.35 \\
\hline D. konu & 50.4 & 19.6 & 30 & $\mathrm{~L}$ & 31.35 & 15.73 & 1.35 \\
\hline E. konu & 56.4 & 13.6 & 30 & $S L$ & 29.65 & 15.59 & 1.35 \\
\hline Organik Materyal & 46.4 & 17.6 & 36 & $\mathrm{~L}$ & 32.67 & 17.18 & 0.84 \\
\hline
\end{tabular}

E: Eser miktarda

ağustos aylarında toplam yağıș 1.00 mm olmuștur. 2016 yllında ortalama sıcaklıklar Haziran' da $27.5^{\circ} \mathrm{C}$, Temmuz'da $30.2^{\circ} \mathrm{C}$ ve Ağustos ayında $29.7^{\circ} \mathrm{C}$ ile uzun yıllar ortalamasının üzerinde gerçekleșmiștir.

Araștırmada Memecik çeșidi zeytin fidanları kullanılmıștır. Bu çeșit, nemli iklim koșullarına uygun, kuraklığa dayanıklı ve denemenin yürütüldüğü Köyceğiz iklim koșullarına iyi adapte olmuș bir çeșittir. Memecik çeșidinin bazı özellikleri, Çizelge 3'de görülmektedir (Anonim, 2013).

Deneme yeri arazisi \% 5 eğimde, așırı tașlı $\%$ 30-50), hafif bünyeli kolüviyal topraklardır. Deneme konu topraklarından alınan örneklerde yapılan bazı fiziksel ve kimyasal analizler Çizelge 4'de verilmiștir.

Düșen her damla suyun toplanarak depolanması, yağıșsız dönemlerde bitkilerin su intiyaçlarını karșılamada oldukça önem tașımaktadır. Mikrohavza su hasadının temel ilkelerinden biri hasat edilen suyun toprakta depolanmasıdır. Yağıșın fazla olduğu araștırma bölgesinde, toprakların tașlı ve su tutma kapasitesinin düșük olușu nedeniyle su toprakta yeterli düzeyde depo edilememektedir. Bundan dolayı toprakta suyun tutulmasını arttırmak için biri kontrol konusu olmak üzere 5 deneme konusu olușturulmuștur. Deneme konularl;

A Kontrol konusu: Dar çukura yöresel dikim,

B konusu: Tașlardan ayıklanmıș toprağa dikim (1x1x1 m'lik fidan çukuruna),

C konusu: B konusu toprağına 50 kg O.G. ilave edilmesi,
D konusu: C konusu toprağına 250 gr polimer (su tutucu) ilave edilmesi,

E konusu: C konusu toprağına 500 gr polimer ilave edilmesi.

Deneme Tesadüf blokları deneme deseninde 3 yinelemeli olacak șekilde kurulmuș olup her konuda üç fidan mevcuttur. Fidan dikimleri $7 \mathrm{~m} \times 7 \mathrm{~m}$ üçgen dikim șeklinde yapıımıș ve tüm konulara mikrohavza su hasadı yöntemlerinden olan yarı dairesel (kaș tipi) seddeler uygulanmıștır. Yarı dairesel seddeler $3 \mathrm{~m}$ yarıçapında, fidan gövdesine $1 \mathrm{~m}$ uzakta olacak șekilde yapıımıștır. Sedde genișliği 40-50 cm, yüksekliği ise 40-45 $\mathrm{cm}$ olacak șekilde mevcut taș ve topraklarla inșa edilmiștir. Fidan dikimleri ve kaș tipi seddelerin yapım tasarımı Șekil 2.1'de verilmiștir. Toprak nem ölçümleri denemenin ikinci tekerrürdeki 2.fidanda $25 \mathrm{~cm}$ ve $75 \mathrm{~cm}$ derinliğe yerleștirilen nem sensörleriyle veriler saatlik olarak alınmıștır. Son iki yıl içerisinde yapılan ișlemler Çizelge 5'te verilmiștir.

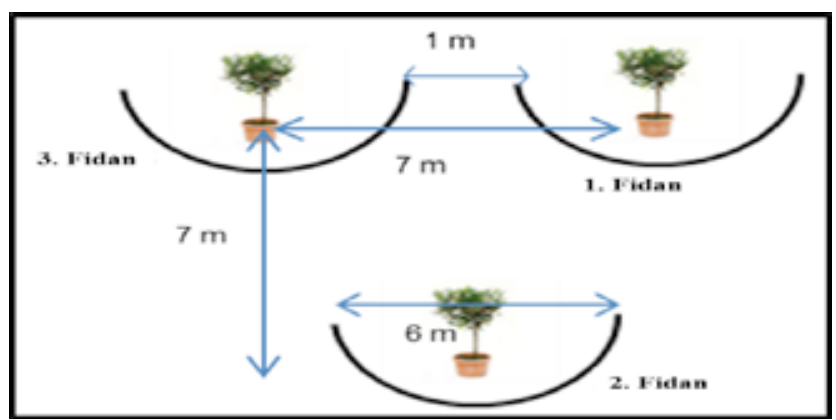

Șekil 1. Fidan dikim șeması

Figure 1. Planting scheme of sapling 
Çizelge 5. Deneme süresince yapılan tarımsal ișlemler

Table 5. Agricultural operations

\begin{tabular}{ll}
\hline Tarih & Denemede yapılan tarımsal ișlemler \\
\hline 24.12 .2014 & Zeytin fidanlarının dikimi \\
05.05 .2015 & Kaș tipi seddelerin yapımı \\
23.06.2015 & Meteoroloji istasyonunun kurulumu ve toprak nem sensörlerin yerleștirilmesi \\
16.10 .2015 & Fidan çap ve boylarının ölçümü \\
25.11 .2015 & Budama ișlemi \\
10.05 .2016 & Yabancı otların temizlenmesi (el ve makine ile) \\
11.08 .2016 & Yabancı otların temizlenmesi (el ve makine ile) \\
18.10 .2016 & Yabancı otların temizlenmesi (el ve makine ile) \\
30.10 .2016 & Fidan cap ve boylarının ölcümü \\
\hline
\end{tabular}
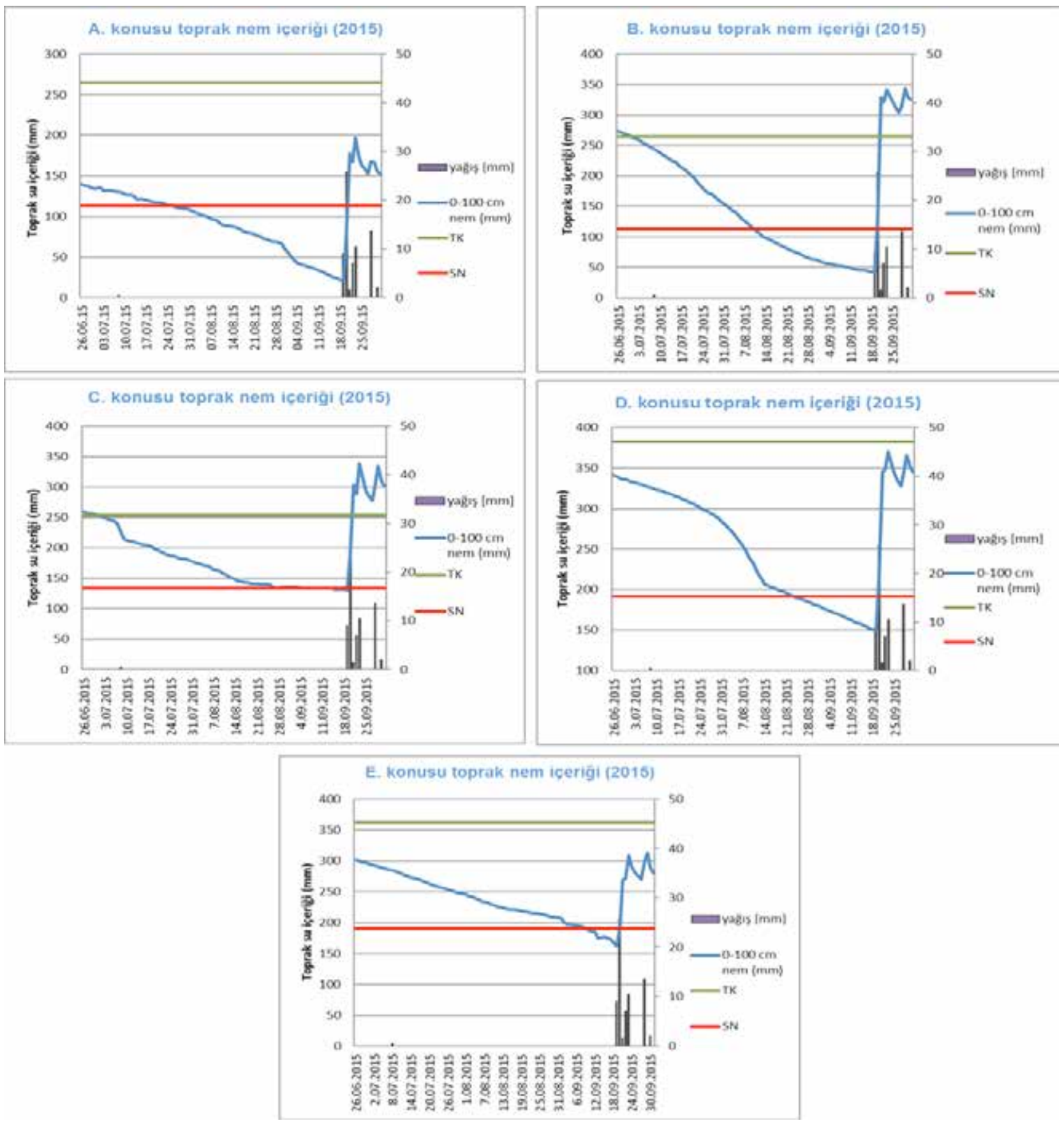

Șekil 2. 2015 yılı deneme konularının toprak nem içeriğinin zamansal değișimi

Figure 2. 2015 year soil moisture content 
Denemede konularındaki fidanların hiçbirine dikim sonrası sulama ve gübreleme yapılmamıș olup günümüze kadar doğal yağıșlarla gelișimlerini sağlamıșlardır.

\section{BULGULAR VE TARTIȘMA}

Deneme konularına ait toprak nem içeriklerin takibinde kullanılan nem sensörleri kalibre edilmiș olup 0-100 cm derinliğindeki nem değerleri hesaplanmıștır. Deneme konularına ait toprak nem içeriklerin zamansal değișim değerleri 2015 yılı Șekil $2^{\prime}$ de verilmiștir.
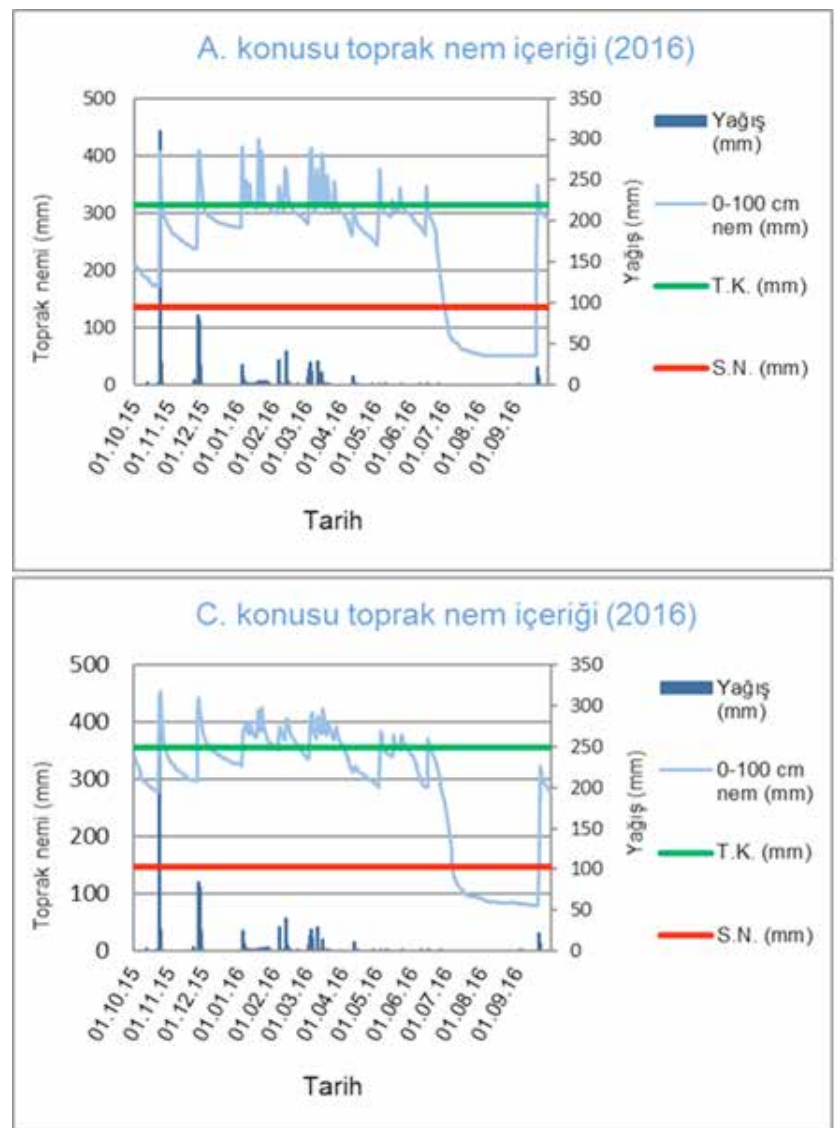

Toprak nem değerleri incelendiğinde 2015 yılında A kontrol konusu nem içeriği Temmuz ayın sonlarına doğru, B konusu toprak nem içeriği Ağustos ayın ortalarında, D konusu toprak nem içeriği Ağustos ayı sonlarına doğru ve E konu toprak nem içeriği ise Eylül ayın bașlarında solma noktası altına düșmüștür. C konusunda ise zeytin fidanı Ağustos ayın sonlarında yapılan çalıșmalar sırasında kırıldığı için toprak nem içeriği solma noktası altına düșmemiștir. Yörede yıl içindeki yağıș dağııımı düzensiz olduğundan 20 Haziran ile 18 Eylül arasında yağıș olmamıștır.
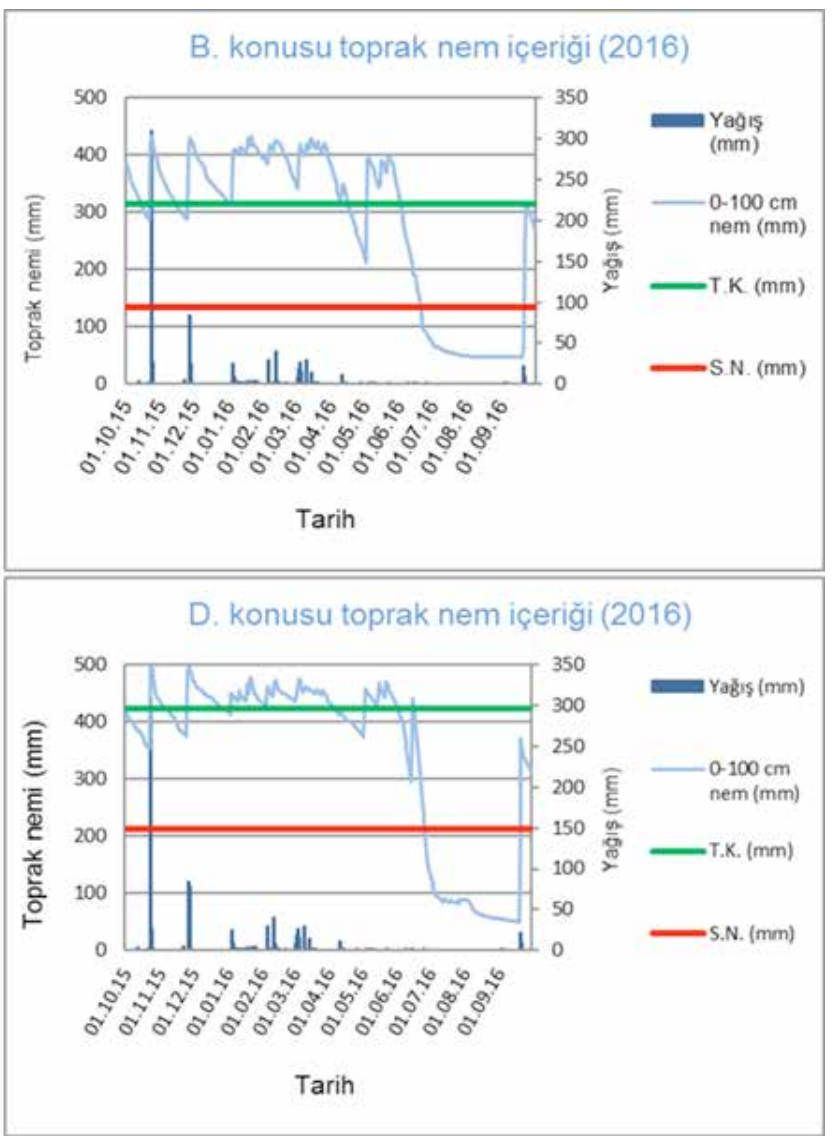

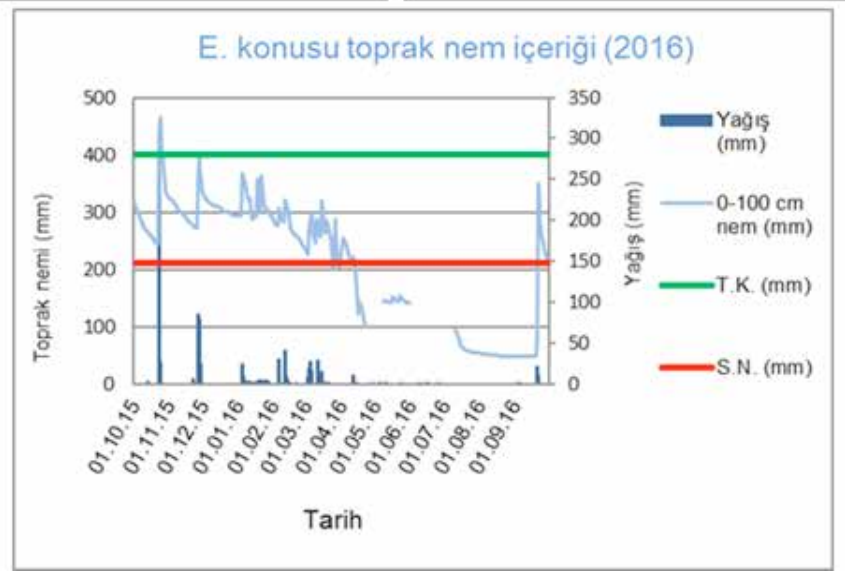

Sekil 3. 2016 ylı deneme konularının toprak nem içeriğinin zamansal değișimi

Figure 3. 2016 year soil moisture content 
2016 yllı toprak nem içeriğinin zamansal değișimi ise Șekil 3'de verilmiștir.

2016 ylında etkili olarak en3 son 11 Nisanda 10 mm yağıș olmuș sonraki yağıș ise 20 Eylülde 20 mm olmuștur.

$\mathrm{Bu}$ verilere göre toprak nem içerik değerleri incelendiğinde yaklașık olarak tüm konular temmuz ayı bașında solma noktası altına düșmüștür. 2015 ve 2016 yıllarındaki toplam yağıș miktarları uzun yıllar ortalamasının (1083mm) altında gerçekleșmiștir.

Fidan çapların ölçümü, dikimde 2014 yılı Aralık ayında, 2015 ve 2016 yılları Ekim ayında yapılmıștır. Konulardaki fidanların ortalama çapları ve hesaplanan gövde kesit alanları ile Duncan grupları Çizelge 6'da verilmiștir. Varyans analiz sonuçları ise Çizelge 7'de verilmiștir.

Buna göre konulardaki fidanların gövde çapı ve gövde kesit alanlarındaki değișim istatistiki analiz sonucunda her iki yılda da \%95 güven seviyesinde önemli çıkmıștır.
2015 yılı fidan gövde kesit alanları dikkate alınarak yapılan değerlendirmede D konusu 133.1 mm² ile ilk sırada yer alırken, bunu 105.5 $\mathrm{mm}^{2}$ ile E konusu, $99.0 \mathrm{~mm}^{2}$ ile C konusu, 94.3 $\mathrm{mm}^{2}$ ile B konusu ve $78.0 \mathrm{~mm}^{2}$ ile A konusu takip etmiștir. Duncan gruplandırmasına göre ise $D$ konusu I. grupta yer almıștır. E, C ve B konuları II. Grupta yer alırken A konusu III. grupta yer almıștır.

2016 yılı fidan gövde kesit alanları dikkate alınarak yapılan değerlendirmede ise D konusu $460.0 \mathrm{~mm}^{2}$ ile yine ilk sırada yer almıștır. Bunu sırasıyla $445.1 \mathrm{~mm}^{2}$ ile B konusu, $432.9 \mathrm{~mm}^{2}$ ile $\mathrm{E}$ konusu, $404.3 \mathrm{~mm}^{2}$ ile C konusu ve $206.7 \mathrm{~mm}^{2}$ ile A konusu takip etmiștir. Duncan gruplandırmasına göre ise D konusu I. grupta yer almıștır. B, E ve C konuları II. grupta yer alırken A konusu III. grupta yer almıștir.

\section{SONUÇLAR}

Proje yöresinde uzun yıllar yağıș ortalaması $1083 \mathrm{~mm}$ olup Türkiye ortalamasının çok

Çizelge 6. Konulara ait fidanların ortalama çap ve gövde kesit alanları

Table 6. Diameter and cross-sectional areas of sapling

\begin{tabular}{ccccccc}
\hline Konu & $\begin{array}{c}2014 \text { Ort. çap } \\
(\mathrm{mm})\end{array}$ & $\begin{array}{c}2015 \text { Ort. çap } \\
(\mathrm{mm})\end{array}$ & $\begin{array}{c}2016 \text { Ort. çap } \\
(\mathrm{mm})\end{array}$ & $\begin{array}{c}2014 \text { Kesit alanı } \\
\left(\mathrm{mm}^{2}\right)\end{array}$ & $\begin{array}{c}2015 \text { Kesit alanı } \\
\left(\mathrm{mm}^{2}\right)\end{array}$ & $\begin{array}{c}2016 \text { Kesit alanı } \\
\left(\mathrm{mm}^{2}\right)\end{array}$ \\
\hline A & 7.8 & $9.9 \mathrm{~B}$ & $15.7 \mathrm{~B}$ & 48.2 & $78.0 \mathrm{~B}$ & $206.7 \mathrm{~B}$ \\
$\mathrm{~B}$ & 7.7 & $10.9 \mathrm{~B}$ & $23.3 \mathrm{~A}$ & 47.7 & $94.3 \mathrm{AB}$ & $445.1 \mathrm{AB}$ \\
$\mathrm{C}$ & 8.1 & $11.2 \mathrm{AB}$ & $22.3 \mathrm{AB}$ & 53.2 & $99.0 \mathrm{AB}$ & $404.3 \mathrm{AB}$ \\
$\mathrm{D}$ & 8.3 & $12.9 \mathrm{~A}$ & $23.9 \mathrm{~A}$ & 56.8 & $133.1 \mathrm{~A}$ & $460.0 \mathrm{~A}$ \\
E & 8.4 & $11.5 \mathrm{AB}$ & $23.3 \mathrm{~A}$ & 56.7 & $105.5 \mathrm{AB}$ & $432.9 \mathrm{AB}$ \\
\hline
\end{tabular}

Çizelge 7. 2015 ve 2016 yıllarında çap ve gövde kesit alanlarına ait varyans analiz tablosu

Table 7. 2015-2016 years variance analysis table

\begin{tabular}{|c|c|c|c|c|c|c|c|}
\hline \multirow{2}{*}{ VK } & \multirow{2}{*}{ SD } & \multicolumn{3}{|c|}{2015} & \multicolumn{3}{|c|}{2016} \\
\hline & & $\mathrm{KO}$ & $\mathrm{F}$ & Prob>F & $\mathrm{KO}$ & $\mathrm{F}$ & Prob $>F$ \\
\hline \multicolumn{8}{|c|}{ Fidan Gövde Capları } \\
\hline Tekerrür & 2 & 1.232 & 2.38 & 0.154 & 45.098 & 8.069 & $0.012^{*}$ \\
\hline Konu & 4 & 3.564 & 6.89 & $0.010 *$ & 34.502 & 6.173 & $0.014^{*}$ \\
\hline Hata & 8 & 0.516 & & & 5.589 & & \\
\hline Genel & 14 & 1.490 & & & 19.494 & & \\
\hline CV & & 6 & 11 & & & & \\
\hline \multicolumn{8}{|c|}{ Fidan Gövde Kesit Alanı } \\
\hline Tekerrür & 2 & 520.041 & 2.712 & 0.126 & 54626.46 & 6.775 & $0.019 *$ \\
\hline Konu & 4 & 1219.416 & 6.358 & $0.013^{*}$ & 32.697 .19 & 4.055 & $0.044^{\star}$ \\
\hline Hata & 8 & 191.782 & & & 8062.851 & & \\
\hline Genel & 14 & 532.286 & & & 21753.178 & & \\
\hline $\mathrm{CV}$ & & & 13 & & & 23 & \\
\hline
\end{tabular}


üzerindedir. Ancak bitkilerin suya en çok ihtiyaç duydukları dönem olan haziran, temmuz ve ağustos aylarında yağıșlar yok denecek kadar azdır. Düzensiz olan bu yağıșlardan daha fazla yararlanmak için, yarı dairesel (kaș tipi) mikrohavza su hasadı yöntemiyle birlikte toprak su tutma kapasitesini iyileștirici bazı uygulamaların zeytin fidan gelișimine etkisini belirlemek amacıyla bu çalıșma yürütülmektedir. Projenin ilk iki yılı sonunda konulardaki zeytin fidanların gövde çapları ve gövde kesit alanlarındaki değișim istatistik olarak önemli çıkmıștır. En geniș gövde çapına D konusu sahip olurken bunu sırasıyla B konusu, E konusu ve C konusu takip etmiștir. Kontrol konusu (yöresel dikim) en küçük gövde kesit alanına sahip olan konu olmuștur.

İki yılın sonunda zeytin fidanlarındaki bu gelișim ve yörede yeni dikilen zeytin fidanların sulama olmadan yetișmediği de dikkate alındığında mikrohavza su hasadının ve toprağın su tutma kapasitesini iyileștirici etmenlerin fidan gelișimine olumlu etkisi olmuștur.

\section{KAYNAKLAR}

Al-Seekh SH, Mohammad AG (2009).The Effect of Water Harvesting Techniques on Runoff, Sedimentation, and Soil Properties Environmental Management.Volume 44, Number $1,37-45$

Anschütz J, Kome A, Nederlof M, De Neef R, Van De Ven T (2003). Water harvesting and soil water retention. Agromisa Foundation. Wageningen.

Anonim (2013). http://z-oliveworld.blogspot. com/2006/02/memecik-zeytin-tr.html Erișim tarihi: 23.01.2013

Boers T, Ben-Asher J (1980). Harvesting water in the desert. In: annual report 1979, International Institute for land reclamation and improvement, Wageningen, Nethelands.

DSi (2013). 3. Ulusal Tașkın Sempozyumu Bildirisi

MGM., (2011). Muğla-Köyceğiz Meteoroloji İstasyonu aylık rasat verileri.

Meteoroloji Genel Müdürlüğü, Ankara.

Oweis T, Hachum A, Kijne J (1999). Water harvesting and supplementary irrigation for improved water use efficiency in dry areas. SWIM paper 7. Colombo, Sri Lanka: International Water Management Institute.

Oweis T, Prinz D, Hachum A (2001). Water Harvesting: Indigenous Knowledge for the Future of the Drier Environments. ICARDA, Aleppo, Syria.40 pp. 